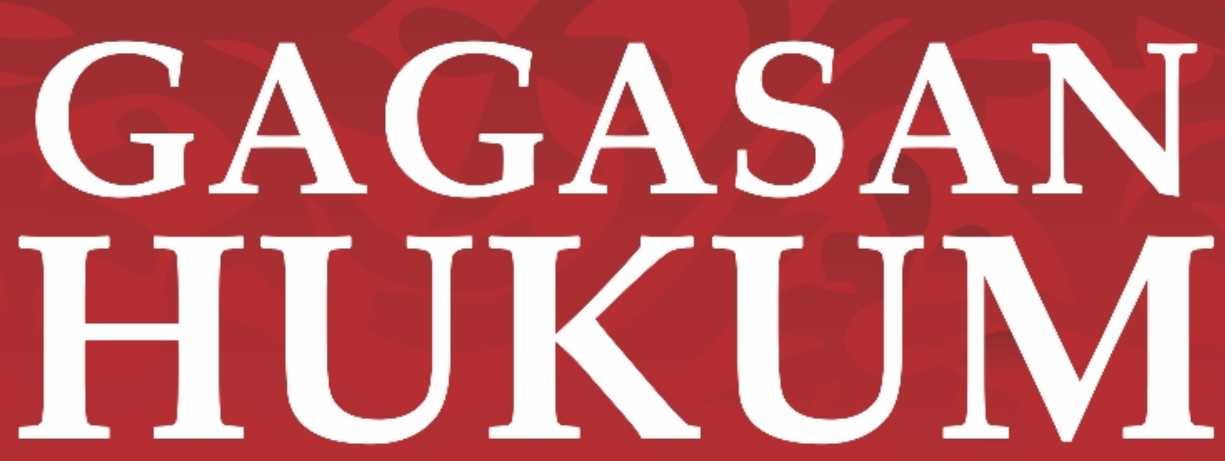

Volume 1 | Nomor 1 | Juni 2019 | Halaman 1-120

\title{
KEKERASAN TERHADAP PEREMPUAN DALAM RUMAH TANGGA SEBAGAI KEJAHATAN KEMANUSIAAN Hanafi Arief
}

MENJERAT PELAKU PENYURUH PENGRUSAKAN BARANG MILIK ORANG LAIN DENGAN MEMPERTIMBANGKAN ASAS FUNGSI SOSIAL Laurensius Arliman $S$

KEWENANGAN PENYELENGGARAAN PROGRAM PENGURANGAN PENGGUNAAN KANTONG PLASTIK DI WILAYAH KOTA BOGOR Nazaruddin Lathif

PENCANTUMAN KOMPOSISI BAHAN PADA LABEL MAKANAN SEBAGAI HAK HUKUM DI KOTA PEKANBARU Riantika Pratiwi

\section{PENEGAKAN HUKUM TINDAK PIDANA KORUPSI DANA DESA DI KABUPATEN KAMPAR \\ Tri Novita Sari Manihuruk}

PORNOGRAFI DUNIA MAYA MENURUT KITAB UNDANG-UNDANG HUKUM PIDANA, UNDANG-UNDANG PORNOGRAFI DAN UNDANG-UNDANG INFORMASI ELEKTRONIK Vera Rimbawani Sushanty

PENEGAKAN HUKUM PENYALAHGUNAAN PENGANGKUTAN BAHAN BAKAR MINYAK BERSUBSIDI DI PROVINSI RIAU BERDASARKAN UNDANG-UNDANG MINYAK DAN GAS BUMI Zulkifli

\section{MAGISTER ILMU HUKUM UNIVERSITAS LANCANG KUNING}




\section{DAFTAR ISI}

\section{HANAFI ARIEF}

Kekerasan Terhadap Perempuan Dalam Rumah Tangga Sebagai Kejahatan Kemanusiaan.

\section{LAURENSIUS ARLIMAN S.}

Menjerat Pelaku Penyruh Pengrusakan Barang Milik Orang Lain Dengan Mempertimbangkan Asas Fungsi Sosial $17-40$

\section{NAZARUDDIN LATHIF}

Kewenangan Penyelenggaraan Program Pengurangan Penggunaan Kantong Plastik Di Wilayah Kota Bogor

\section{RIANTIKA PRATIWI}

Pencantuman Komposisi Bahan Pada Label Makanan Sebagai Hak Hukum Di Kota Pekanbaru

\section{TRI NOVITA SARI MANIHURUK}

Penegakan Hukum Tindak Pidana Korupsi Dana Desa Di Kabupaten Kampar

88-108

\section{VERA RIMBAWANI SUSHANTY}

Pornografi Dunia Maya Menurut Kitab Undang-Undang Hukum Pidana, UndangUndang Pornografi dan Undang-Undang Informasi Elektronik. 109-129

\section{ZULKIFLI}

Penegakan Hukum Penyalahgunaan Pengangkutan Bahan Bakar Minyak Bersubsidi Di Provinsi Riau Berdasarkan Undang-Undang Minyak Dan Gas Bumi 


\title{
KEWENANGAN PENYELENGGARAAN PROGRAM PENGURANGAN KANTONG PLASTIK DI WILAYAH KOTA BOGOR
}

\author{
Nazaruddin Lathif \\ Fakultas Hukum Universitas Pakuan Bogor \\ Email: nay.nazar@yahoo.co.id
}

\section{Info Artikel:}

Diterima: 15 Juni 2019

Disetujui: 28 Juli 2019

Dipublikasikan: 24 September 2019

\begin{abstract}
Abstrak
Sampah menjadi masalah pencemaran lingkungan di Indonesia. Oleh karena itu, Pemerintah Kota Bogor menekankan pentingnya penggunaan kantong plastik saat berbelanja. Penelitian ini bertujuan untuk memberikan pemahaman kepada masyarakat terkait terbitnya Peraturan Walikota Bogor Nomor 61 Tahun 2018 tentang Penggurangan Penggunaan Kantong Plastik. Metode penelitian yang digunakan, yaitu yuridis normatif dan yuridis empiris. Kewenangan Pemerintah Kota Bogor menyelenggarakan program pengurangan kantong plastik, yaitu Peraturan Walikota Bogor Nomor 61 Tahun 2018 tentang Pengurangan Penggunaan Kantong Plastik dan Undang-Undang Nomor 18 tahun 2008 tentang Pengolaan Sampah, dan UndangUndang Nomor 23 Tahun 2014 tentang Pemerintah Daerah. Penelitian ini menyimpulkan bahwa dalam menyelenggarakan program pengurangan kantong plastik, Pemerintah Daerah Kota Bogor mempunyai kewenangan, yaitu menetapkan kebijakan dan strategis partisipasi masyarakat dalam pengurangan penggunaan kantong plastik, pembinaan, pengawaasan, dan evaluasi secara periodik terhadap penggunaan kantong plastik oleh pelaku usaha, pusat perbelanjaan, toko modern, dan/atau masyarakat yang menjadi konsumen.
\end{abstract}

Kata kunci: Kewenangan, Sampah, Kantong plastik

\section{AUTHORITY OF PROGRAMS FOR REDUCING PLASTIC BAGS IN BOGOR CITY AREA}

\begin{abstract}
Rubbish is a problem of environmental pollution in Indonesia. Therefore, the Bogor City Government encouraged the importance of using plastic bags when shopping. This study aims to provide understanding to the public regarding the issuance of Bogor Mayor Regulation Number 61 of 2018 concerning Reducing the Use of Plastic Bags. The research method used is normative juridical and empirical juridical. The authority of the Bogor City Government organizes a plastic bag reduction program, namely the Bogor Mayor Regulation Number 61 of 2018 concerning Reducing the Use of Plastic Bags and Law Number 18 of 2008 concerning Waste Management, and Law Number 23 of 2014 concerning Regional Government. This study concluded that in carrying out a plastic bag reduction program, the Regional Government of Bogor City has the authority, namely establishing policies and strategic community participation in reducing the use of plastic bags, fostering, supervising and periodically evaluating the use of plastic bags by businesses, shopping centers, modern stores, and/or communities that become consumers.
\end{abstract}

Keywords: Authority, Rubbish, Plastic bags 
Kewenangan Penyelenggaraan Program.....

\section{Nazaruddin Lathif}

\section{A. PENDAHULUAN}

Hukum lingkungan merupakan instrumen administrasi negara dalam perlindungan dan pengelolaan lingkungan hidup. Hukum lingkungan menjadi pedoman dalam rangka perlindungan dan pengelolaan lingkungan hidup tersebut. Norma perlindungan dan pengelolaan lingkungan hidup menjadi pedoman dalam penyelenggaraan perizinan bidang lingkungan hidup. Undang-Undang Dasar Negara Republik Indonesia Tahun 1945 disingkat UUD 1945 menyatakan bahwa lingkungan hidup yang baik dan sehat merupakan hak asasi dan hak konstitusional bagi setiap warga negara Indonesia. ${ }^{1}$ Pemerintah dan seluruh unsur masyarakat wajib memberikan perlindungan dan pengelolaan lingkungan hidup dalam pembangunan berkelanjutan agar lingkungan hidup Indonesia senantiasa menjadi sumber daya dan penunjang hidup rakyat Indonesia.

Pasal 33 ayat (3) UUD 1945 mengatur norma dasar pengelolaan lingkungan hidup bahwa Bumi dan air dan kekayaan alam yang terkandung di dalamnya dikuasai oleh negara dan dipergunakan untuk sebesar-besar kemakmuran rakyat. Peraturan Perundang- undangan di bawahnya Undang-Undang Nomor 32 Tahun 2009 tentang Perlindungan dan Pengelolaan Lingkungan Hidup, Pasal 1 angka 2 menyebutkan bahwa perlindungan dan pengelolaan lingkungan hidup adalah upaya sistematis dan terpadu yang dilakukan untuk melestarikan fungsi lingkungan hidup dan mencegah terjadinya pencemaran dan/atau kerusakan lingkungan hidup yang meliputi perencanaan, pemanfaatan, pengendalian, pemeliharaan, dan penegakan hukum. Kemudian Pasal 1 angka 1 Undang-Undang Nomor 32 Tahun 2009 menjelaskan lingkungan hidup adalah kesatuan ruang dengan semua benda, daya, keadaan, dan makhluk hidup termasuk di dalamnya manusia dan perilakunya yang memengaruhi kelangsungan kehidupan dan kesejahteraan manusia serta makhluk hidup lainnya. Manusia hanya salah satu unsur dalam lingkungan hidup, akan tetapi perilakunya mempengaruhi kelangsungan kehidupan dan kesejahteraan manusia dan makhluk lain. ${ }^{2}$ Adanya hubungan timbal balik antara makhluk hidup dengan lingkungannya menunjukkan makhluk hidup dalam kehidupannya

\footnotetext{
2 Andi Hamzah, Penegakan Hukum Lingkungan, (Jakarta: Sinar Grafika, 2005), hlm. 1.
} Perlindungan dan Pengelolaan Menuju Ekokrasi Indonesia, Kanun Jurnal Ilmu Hukum, Vol. 18, No. 1, April, 2016, hlm. 51. 
senantiasa

berinteraksi

dengan

lingkungannya. ${ }^{3}$

Sampah selalu menjadi masalah pencemaran lingkungan hidup di kota-kota besar dunia, termasuk juga Indonesia. Manusia dengan kemajuan teknologi dihadapkan masalah sampah plastik. Tingginya pola konsumsi manusia telah menambah produksi sampah. Sampah yang menumpuk dan berbau merupakan pemandangan yang biasa ditemui setiap hari di berbagai sudut kota. Permasalahan sampah di kawasan perkotaan disebabkan beberapa parameter yang saling berhubungan, yaitu pertumbuhan penduduk, pertumbuhan ekonomi, pola konsumsi masyarakat, perilaku penduduk, kepadatan penduduk dan bangunan. Berbagai penanganan sampah di telah mencapai tahap kritis, utamanya sampah plastik yang diklaim ramah lingkungan pun sulit terpecahkan ditambah lagi daya daur ulang alam tidak lagi mendukungnya. Wajar bila sampah menjadi masalah yang tidak henti hentinya dibahas. ${ }^{4}$

Penggunaan kantong plastik menjadi salah satu penyebab timbulnya sampah. Sampah plastik di wilayah Kota Bogor

3 Muhammad Akib, Hukum Lingkungan, Perspektif Global dan Nasional, Edisi Revisi, (Jakarta: Raja Grafindo Persada, 2014), hlm. 2.

4 Jailan Sahili, Mimien Henie Irawati Al Muhdar, Fachtur Rohman, dan Istamar Syamsuri, mencapai 700 ton perhari. Dengan jumlah sampah plastik yang diperkirakan bisa mencapai 100 ton perhari. Berkaitan hal tersebut, Pemerintah Kota Bogor bergerak untuk menekan penggunaan plastik, khususnya kantong plastik yang biasa dipergunakan saat berbelanja. Hasilnya, Pemerintah Kota Bogor menerbitkan Peraturan Walikota Nomor 61 Tahun 2018 tentang Pengurangan Penggunaan Kantong Plastik. Peraturan ini ditujukan untuk melindungi wilayah Kota Bogor dari pencemaran dan kerusakan lingkungan yang diakibatkan oleh penggunaan kantong plastik serta menjamin kelangsungan kehidupan makhluk hidup dan kelestarian ekosistem juga menjamin keselamatan, kesehatan, dan kehidupan warga dari ancaman pencemaran dan kerusakan lingkungan hidup.

\section{Pemberlakuan Peraturan Walikota} Nomor 61 Tahun 2018 bertujuan agar dapat mengatasi permasalahan penggunaan kantong plastik yang telah mengakibatkan penumpukan sampah selama ini khususnya di wilayah Kota Bogor. Peraturan Walikota Nomor 61 Tahun 2018 telah melarang

Sistem Pengelolaan dan Upaya Penanggulangan Sampah Di Kelurahan Dufa-Dufa Kota Ternate, Jurnal Bioedukasi, Vol. 4, No. 2, Maret 2016, hlm. 478. 
Kewenangan Penyelenggaraan Program.....

\section{Nazaruddin Lathif}

penggunaan kantong plastik yang ditujukan kepada pelaku usaha, pusat perbelanjaan, dan toko retail modern. Sepatutnya semua pihak ikut mendukung dan melaksanakan Peraturan Walikota Nomor 61 Tahun 2018 baik dari pihak konsumen maupun pihak dari retail toko modern.

Dalam perkembangannya, meskipun Peraturan Walikota Nomor 61 Tahun 2018 melarang penggunaan kantong plastik, namun peraturan tersebut belum terlaksana sebagaimana mestinya. Pertanyaannya, bagaimana kewenangan Pemerintah Kota Bogor Dalam Penyelenggaraan Pengurangan Kantong Plastik, bagaimana embinaan dan Pengawasan Terhadap Pelaku Produsen dan Pelaku Usaha Dalam Kaitannya Dengan Program Pengurangan Kantong Plastik, apa kendala-Kendala Yang Dihadapi Pemerintah Kota Bogor Dalam Program Pengurangan Kantong Plastik. Tulisann ini menjawab beberapa pertanyaan tersebut.

\section{B. METODE PENELITIAN}

Penelitian hukum adalah suatu proses menemukan aturan hukum, prinsip-prinsip hukum, maupun doktrin-doktrin hukum untuk

\footnotetext{
${ }^{5}$ Peter Mahmud Marzuki, Penelitian Hukum, (Jakarta: Kencana Prenada Media Group, 2010), hlm. 35 .
}

menjawab isu hukum yang dihadapi. $^{5}$ Penelitian hukum merupakan suatu kegiatan ilmiah yang didasarkan pada metode, sistematika, dan pemikiran tertentu yang bertujuan untuk mempelajari satu atau beberapa gejala hukum tertentu dengan cara menganalisisnya. ${ }^{6}$

Jenis penelitian ini menggunakan jenis penelitian yuridis empiris, yaitu penelitian dengan cara wawancara yang merupakan data primer dan dikenal dengan penelitian lapangan. Data yang diperlukan dalam penelitian ini ialah data primer dan sekunder. Data primer diperoleh melalui penelitian lapangan, yaitu menggunakan teknik wawancara terhadap beberapa narasumber yang berkompeten dibidangnya. Pengumpulan data primer bertujuan untuk menggali data dan informasi faktual. Data primer diperoleh dengan cara survai dan observasi dengan mendeskripsikan setiap parameter pengamatan baik secara kualitatif dan kuantitatif melalui panduan daftar pertanyaan (kuesioner) dan diskusi dengan setiap responden yang dilakukan dengan teknik purposive sampling. Penentuan lokasi pengamatan dan penetapan responden tidak sekedar berdasarkan

\footnotetext{
${ }^{6}$ Soerjono Soekanto, Pengantar Penelitian Hukum, (Jakarta: UI Press, 1986), hlm. 43.
} 
pertimbangan representatif wilayah studi, akan tetapi lebih ditekankan pada relevansi terhadap problem lingkungan berdasar isu pokok. ${ }^{7}$

\section{HASIL DAN PEMBAHASAN}

\section{Kewenangan Pemerintah Kota Bogor \\ Dalam Penyelenggaraan Pengurangan Kantong Plastik}

Pada prinsipnya kewenangan merupakan kekuasaan untuk melakukan tindakan hukum publik yang direalisasikan sebagai hak untuk menjalankan pemerintahan dan hak untuk dapat secara konkrit mempengaruhi suatu keputusan yang akan diambil oleh pemerintah selaku penyelenggara negara. ${ }^{8}$

Transformasi kota menjadi kawasan metropolitan sering terjadi pada berbagai negara, termasuk kota besar di Indonesia. ${ }^{9}$ Kawasan metropolitan merupakan perwujudan perkembangan yang alamiah dari suatu proses globalisasi yang berkembang sangat pesat. Perkembangan tersebut menyebabkan peningkatan jumlah penduduk yang sangat

\footnotetext{
${ }^{7}$ Ibid., hlm. 52.

8 Safri Nugraha, Hukum Administrasi Negara, (Jakarta: FH UI, 2007), hlm. 29.

9 Arrauda Vioya, Tahapan Perkembangan Kawasan Metropolitan Jakarta Jurnal Perencanaan Wilayah dan Kota, Vol. 21, No. 3, Desember 2010, hlm. 215.

${ }^{10}$ Said Usman, Strategi Pengelolaan Sampah Rumah Tangga Di Kota Tarakan Kalimantan Utara,
}

besar dengan karateristik dan persoalan yang berbeda dan spesifik. Oleh karena itu, suatu perkotaan memerlukan pengelolaan tersendiri untuk memecahkan suatu masalah.

Sampah merupakan permasalahan yang krusial. Sampah menjadi masalah kultural karena dampaknya bisa terkena pada berbagai sisi kehidupan. ${ }^{10}$ Sampah bisa menjadi penyebab kerusakan lingkungan diantaranya penumpukan sampah yang berasal dari industri maupun rumah tangga. ${ }^{11}$ Hingga kini, sampah merupakan persoalan perkotaan yang tidak kunjung selesai. Pengelolaan sampah perkotaan yang tidak tuntas, tidak saja menyebabkan situasi lingkungan perkotaan nampak tidak estetis, namun juga menimbulkan berbagai persoalan, seperti banjir, pencemaran lingkungan, penurunan derajat kesehatan masyarakat, dan masalah sosial. Sampah akan terus diproduksi selama manusia hidup. Jumlah sampah yang dihasilkan oleh penduduk bumi ini akan semakin meningkat. Sampah merupakan salah satu bentuk konsekuensi adanya kegiatan

Jurnal Ekonomi Pembangunan, Vol. 5, N0 3, November 2016, hlm. 350

${ }^{11}$ Ayi Indah Novianti dan Lindawati Kartika, Pengaruh Green Marketing Kebijakan Kantong Plastik Berbayar Terhadap Green Behaviour Masyarakat Kota Bogor, Jurnal Riset Manajemen dan Bisnis Vol. 2, No. 1, hlm. 82. 


\section{Nazaruddin Lathif}

manusia dan volumenya berbanding lurus dengan jumlah penduduk. Apabila tidak ditangani secara efektif dan efisien, maka sampah akan menghancurkan kehidupan manusia. $^{12}$

Pengurangan sampah adalah pembatasan timbulan sampah, pendaurulangan sampah, dan/atau pemanfaatan kembali sampah. ${ }^{13}$ Kegiatan pengurangan sampah bertujuan agar seluruh lapisan masyarakat, baik pemerintah, dunia usaha maupun masyarakat luas melaksanakan kegiatan pembatasan timbulan sampah, pendauran ulang dan pemanfaatan kembali sampah yang lebih dikenal dengan Reduce, Reuse, dan Recycle (3R). Kegiatan 3R ini masih menghadapi kendala utama, yaitu rendahnya kesadaran masyarakat untuk memilah sampah dan masih banyaknya dihasilkan sampah non-organik yang tidak dapat diurai dengan cepat seperti plastik.

Paradigma baru dalam suatu pembangunan adalah lebih mengutamakan perencanaan dari bawah (bottom-up) untuk menghasilkan partisipasi maksimal dari masyarakat yang terlibat dalam proses

\footnotetext{
12 Hijrah Purnama Putra dan Yebi Yuriandala, Studi pemanfaatan Sampah Plastik Menjadi Produk dan Jasa Kreatif, urnal Sains dan Teknologi Lingkungan, Volume 2, Nomor 1, Januari 2010, hlm. 21.
}

pembangunan. Proses pembangunan yang sebenarnya, haruslah merupakan perubahan sosial budaya. Agar pembangunan menjadi proses yang dapat bergerak maju sendiri (self sustaining process) tergantung pada manusia dan struktur sosialnya. Demikian juga masalah pengelolaan sampah di perkotaan, apabila menginginkan dapat terselesaikan secara mendasar, maka masyarakat harus diberdayakan secara optimal. Oleh karena masalah sampah plastik menjadi permasalahan terutama di kota-kota besar, maka masyarakat perlu dilibatkan dalam upaya penanganan sampah plastik tersebut.

Kewenangan pemerintah Kota Bogor dalam program pengurangan kantong plastik didasari atas dikeluarkannya Peraturan Walikota Nomor 61 Tahun 2018 tentang Pengurangan Penggunaan Kantong Plastik yang diundangkan dalam Berita Daerah Kota Bogor Nomor 43 Tahun 2018 Seri E tanggal 23 Juli 2018. Dalam hal ini yang menjadi landasan dikeluarkan Peraturan Walikota adalah dalam rangka meningkatkan kesadaran masyarakat untuk mewujudkan lingkungan yang terjaga dengan baik dan

13 Rosita Shochib, Pengelolaan Sampah kantor Secara Terpadu (Studi Kasus Kantor BPPT), Jurnal Rekayasa Lingkungan, Vol. 7, No. 2, Juli 2011, hlm. 154 . 
berkesinambungan. Diperlukan partisipasi berbagai pihak untuk menjaga dan meningkatkan kelestarian lingkungan serta penggunaan kantong plastik telah menjadi permasalahan terhadap lingkungan sehingga perlu dilakukan upaya pengendalian terhadap dampak kurang baik dari kantong plastik secara komprehensif dan terpadu dari hulu agar memberikan rasa aman, bersih, dan sehat bagi lingkungan hidup.

Pada kenyataannya, produk barang plastih memang dibutuhkan masyarakat, namun berdampak buruk terhadap lingkungan. ${ }^{14}$ Kantong plastik menimbulkan dampak pencemaran yang berbahaya bagi lingkungan karena sulit terurainya sampah kantong plastik tersebut. Pencemaran lingkungan akibat sampah plastik makin mengkhawatirkan jika tidak diusahakan untuk mengatasinya. Masyarakat yang kurang berpengetahuan dan berperilaku buruk mengelola sampah plastik bisa menimbulkan gangguan kesehatan dan lingkungan. ${ }^{15}$ Berkenaan hal tersebut, Pasal 1 angka 7 Peraturan Walikota Bogor Nomor 61 tahun

${ }^{14}$ Firman L Sahwan, Joko Heru Martono, Sri Wahyono, dan Lies A Wisoyodharmo, Sistem Pengelolaan Libah Plastik di Indonesia, Jurnal Teknologi Lingkungan, Vol. 6, No. 1, 2011, hlm. 311..

15 Ririn Setyowati, Surahma Asti Mulasari, Pengetahuan dan Perilaku Ibu Rumah Tangga dalam Pengelolaan Sampah Plastik, Jurnal Kesehatan
2018 menyatakan bahwa kantong plastik yang tidak ramah lingkungan adalah kantong plastik yang karena bahan-bahan dasar pembuatannya, atau reaksi kimia antara bahanbahan dasar tersebut, atau karena sifat, konsentrasinya dan/atau jumlahnya mengakibatkan kesulitan dalam penguraian kembali proses alamiah, sehingga secara langsung maupun tidak langsung dapat mencemarkan dan/atau merusak kualitas lingkungan hidup baik secara permanen atau setidak-tidaknya untuk waktu yang proses alami.

Indonesia adalah negara kedua terbesar setelah Tiongkok penyumbang sampah plastik yang di buang ke laut. ${ }^{16}$ Sampah plastik merupakan sampah yang paling banyak dibuang oleh manusia karena banyak orang yang menggunakan plastik untuk keperluannya sehari-hari baik perorangan, toko, maupun perusahaan besar. Pembuangan sampah plastik ke dalam air dan tanah telah menambah tingkat kesengsaraan alam. Hal ini disebabkan sampah plastik terbuat dari bahan anorganik. Bahan anorganik tidak mungkin

Masyarakat Nasional, Vol. 7, No. 12, Juli 2013, hlm. 562.

${ }^{16}$ Sri Nurhayati Qodriyatun, Sampah Plastik: Dampaknya Terhadap Pariwisata dan Solusinya, Jurnal kajian Singkat Terhadap Isu Aktual dan Strategis Vol. X, No. 23, Desember 2018, hlm. 13. 
Kewenangan Penyelenggaraan Program.....

\section{Nazaruddin Lathif}

diuraikan oleh bakteri pengurai. Apabila ditimbun dalam tanah, butuh waktu berjutajuta tahun hingga sampah plastik tersebut dapat diuraikan. Apabila dibakar berpotensi mengeluarkan dioksin yang berbahaya bagi kesehatan, residu plastik akan menjadi gumpalan, dan butuh waktu lama untuk mengurainya.

Berdasarkan hal tersebut, Pemerintah

Daerah Kota Bogor mempunyai tugas menjamin terselenggaranya pengurangan penggunaan kantong plastik demi mengurangi dampak yang ditimbulkan akibat adanya sampah plastik. Tugas dan wewenang pemerintah Kota Bogor dalam penyelenggaraan pengurangan kantong plastik terdapat dalam Bab II Pasal 4 dan Pasal 5. Adapun yang menjadi tugas Pemerintah Kota Bogor yang termuat dalam Pasal 4 Peraturan Walikota Bogor Nomor 61 tahun 2018.

Berbagai Pemerintah Daerah sudah menerapkan kebijakan pembatasan penggunaan kantong plastik, seperti Banjarmasin, Balikpapan, Denpasar, Bogor, dan lain-lain. Peraturan pengurangan kantong plastik berkaitan dengan masalah lingkungan hidup merupakan kewajiban bagi Pemerintah Daerah untuk mencegah kerusakan lingkungan hidup. Pasal 17 ayat (1) Peraturan Walikota Bogor Nomor 61 tahun 2018 menyetakan seluruh toko modern dan pusat perbelanjaan di Kota Bogor dilarang menyediakan kantong plastik. Direktur Pengelolaan Sampah Direktorat Jenderal Pengelolaan Limbah, Sampah, dan Bahan Beracun Berbahaya (PSLB3) Kementerian Lingkungan Hidup dan Kehutanan Pemerintah Pusat mendukung berbagai inisiatif di berbagai daerah dalam upaya mengendalikan sampah plastik.

Pasal 8 Peraturan Walikota Bogor Nomor 61 Tahun 2018 telah menetapkan kawasan pengurangan penggunaan kantong plastik berdasarkan pada intensitas penggunaan dan potensi pencemaran lingkungan di pusat perbelanjaan dan pertokoan modern. Pasal 1 angkat 11 Peraturan Walikota Bogor Nomor 61 Tahun 2018 menyebutkan Pusat Perbelanjaan adalah suatu area tertentu yang terdiri dari satu atau beberapa bangunan yang didirikan secara vertikal maupun horizontal, yang dijual atau disewakan kepada pelaku usaha atau dikelola sendiri untuk melakukan kegiatan perdagangan barang. Sementara itu, Toko Modern adalah toko dengan sistem pelayanan mandiri, menjual berbagai jenis barang secara eceran yang berbentuk minimarket, supermarket, Departemen Store, Hypermarket, ataupun grosir yang berbentuk 
perkulakan.

Larangan menyediakan kantong plastik ditegaskan dalam Pasal 11 Peraturan Walikota Bogor Nomor 61 tahun 2018 yang menyatakan bahwa Seluruh Pusat Perbelanjaan dan Toko Modern dilarang untuk menyediakan kantong plastik. Sementara Pasal 12 Peraturan Walikota Bogor Nomor 61 Tahun 2018 menjelaskan niat serius Pemerintah Daerah Kota Bogor dapat terlihat dalam menentukan kebijakan pengurangan penggunaan kantong plastik sebagai salah satu upaya pencegahan melalui persyaratan perizinan usaha. Pasal 17 ayat (1) Peraturan Walikota Bogor Nomor 61 Tahun 2018 menyebutkan Wali Kota Bogor atau pejabat yang membidangi lingkungan hidup dan Perangkat Daerah yang terkait melakukan pengawasan terhadap Pelaku Usaha, Pusat Perbelanjaan, dan Toko Modern.

Pasal 17 ayat (3) Peraturan Walikota Bogor Nomor 61 tahun 2018 menyatakan apabila ada ketidaktaatan dari pelaku usaha maupun pengguna kantong plastik, maka Walikota Bogor melakukan pembinaan melalui sosialisasi, konsultasi, dan pelatihan. Pasal 12 ayat (2) huruf d Peraturan Walikota Bogor Nomor 61 tahun 2018 menyatakan bahwa Wali Kota Bogor wajib mendorong penggunaan kantong lain sebagai alternatif pengganti kantong plastik. Alternatif kantong plastik terdapat dalam Pasal 13 Peraturan Walikota Bogor Nomor 61 Tahun 2018 yang menyatakan bahwa Setiap pelaku usaha dan penyedia kantong plastik wajib mengupayakan kantong plastik atau kantong alternatif lain yang ramah lingkungan.

Pasal 1 angka 6 Peraturan Walikota Bogor Nomor 61 tahun 2018 menyebutkan bahwa Kantong plastik yang ramah lingkungan adalah kantong plastik yang mudah diurai dalam proses alami dan jumlah, sifat dan/atau konsentrasinya tidak akan mencemari dan/atau merusak lingkungan hidup berdasarkan hasil pengujian laboratorium. Pasal 1 angka 8 Peraturan Walikota Bogor Nomor 61 tahun 2018 menyebutkan bahwa kantong ramah lingkungan lainnya adalah kantong yang terbuat dari atau tidak mengandung bahan dasar plastik dan terbuat dari bahan dasar organik yang mudah terurai, dan/atau kantong permanen yang dapat dipakai berulang-ulang. Pasal 12 ayat (2) huruf c Peraturan Walikota Bogor Nomor 61 tahun 2018 menyatakan bahwa Selain melarang pelaku usaha, Pemerintah Daerah Kota Bogor juga wajib mendorong dan mendukung masyarakat untuk melakukan pengurangan penggunaan kantong plastik secara mandiri. 
Kewenangan Penyelenggaraan Program.....

\section{Nazaruddin Lathif}

Pasal 14 ayat (2) Peraturan Walikota Bogor Nomor 61 Tahun 2018 menyebutkan bahwa pengguna kantong plastik berkewajiban mengurangi penggunaan kantong plastik dan berperan serta dalam melakukan sosialisasi bahaya penggunaan kantong plastik yang tidak ramah lingkungan. Hal tersebut dilakukan agar seluruh masyarakat mengerti dan peduli akan lingkungan dan pentingnya pengurangan penggunaan kantong plastik sebagai cara untuk meminimalisasi volume, distribusi dan penggunaan secara bijaksana serta bertahap akan mengurangi ketergantungan terhadap kantong plastik yang tidak ramah lingkungan.

Ada beberapa peraturan yang menjadi rujukan penyelenggaraan pengurangan kantong plastik yaitu diantaranya adalah Undang-Undang Nomor 32 Tahun 2009 tentang Perlindungan dan Pengelolaan Lingkungan Hidup, Undang-Undang Nomor 18 Tahun 2008 tentang Pengelolaan Sampah, Peraturan Pemerintah Nomor 81 tahun 2012 tentang Pengelolaan Sampah Rumah Tangga dan Sampah Sejenis Sampah Rumah Tangga, Peraturan Presiden Nomor 97 Tahun 2017 tentang Kebijakan dan Strategi Nasional

\footnotetext{
${ }^{17}$ Arieyanti Dwi Astuti, Penerapan Kantong Plastik Berbayar Sebagai Upaya Mereduksi
}

Pengelolaan Sampah Rumah Tangga dan Sampah Sejenis Sampah Rumah Tangga, Peraturan Daerah Kota Bogor Nomor 9 Tahun 2012 tentang Pengelolaan Sampah serta Surat Edaran Kementerian Lingkungan Hidup dan Kehutanan di bawah Dirjen Pengelolaan Sampah, Limbah, dan Bahan Beracun Berbahaya (Nomor S.1230/P SLB3-PS/2016), surat tersebut ditujukan kepada kepala daerah dan pelaku usaha, mengenai penerapan plastik berbayar di seluruh gerai pasar modern di Indonesia. Pemerintah berharap penerapan berbagai kebijakan tersebut bisa diminimalisir penggunaan kantong plastik sehingga bisa ditekan jumlah sampah plastik. ${ }^{17}$

Pasal 14 huruf i Undang-Undang Nomor 32 Tahun 2009 tentang Perlindungan dan Pengelolaan Lingkungan Hidup menyebutkan bahwa salah satu instrumen pencegahan pencemaran dan/atau kerusakan lingkungan hidup adalah peraturan perundangundangan berbasis lingkungan hidup. Untuk itu, berkaitan dengan sampah dapat kita lihat ketentuannya dalam Undang-Undang Nomor 18 Tahun 2008 tentang Pengelolaan Sampah. Pasal 29 ayat (1) Undang-Undang Nomor 18 Tahun 2008 tentang Pengelolaan Sampah

Penggunaan Kantong Plastik, Jurnal Litbang, Vol. XII, No. 1 Juni 2016, hlm. 37. 
menyebutkan bahwa setiap orang dilarang memasukkan sampah ke dalam wilayah Negara Kesatuan Republik Indonesia, mengimpor sampah, mencampur sampah dengan limbah berbahaya dan beracun, mengelola sampah yang menyebabkan pencemaran dan/atau perusakan lingkungan, membuang sampah tidak pada tempat yang telah ditentukan dan disediakan, melakukan penanganan sampah dengan pembuangan terbuka di tempat pemrosesan akhir dan/atau, membakar sampah yang tidak sesuai dengan persyaratan teknis pengelolaan sampah.

Sampah yang dikelola berdasarkan Pasal 2 Undang-Undang Nomor 18 Tahun 2008 tentang Pengelolaan Sampah terdiri atas. sampah rumah tangga (berasal dari kegiatan sehari-hari dalam rumah tangga, tidak termasuk tinja dan sampah spesifik), sampah sejenis sampah rumah tangga (berasal dari kawasan komersial, kawasan industri, kawasan khusus, fasilitas sosial, fasilitas umum, dan/atau fasilitas lainnya), sampah spesifik (meliputi sampah yang mengandung bahan berbahaya dan beracun, sampah yang secara teknologi belum dapat diolah, dan lain sebagainya). Setiap orang dalam pengelolaan

${ }^{18}$ Husnul Khatimah, Diet Kantong Plastik di Bogor Kurangi 41 Ton Sampah, https://www.ayobogor.com/read/2019/02/18/2530/diet- sampah rumah tangga dan sampah sejenis sampah rumah tangga wajib mengurangi dan menangani sampah dengan cara yang berwawasan lingkungan. Ketentuan lebih lanjut mengenai tata cara pelaksanaan kewajiban pengelolaan sampah rumah tangga dan sampah sejenis sampah rumah tangga diatur dengan peraturan daerah.

Berkaitan dengan diet kantong plastik yang diterapkan Pemerintah Kota Bogor sejak tanggal 01 Desember 2018 berhasil mengurangi sampah plastik. Retail dan Pusat Perbelanjaan dalam waktu hampir 3 (tiga) bulan mampu mengurangi sampah plastik sebanyak 41 (empat puluh satu) ton. Pengurangan 41 (empat puluh satu) ton itu dari 24 (dua puluh empat) retail yang menerapkan Program Bogor Tanpa Plastik (Botak). ${ }^{18}$ Dua tahun yang lalu, kebijakan hampir serupa kantong plastik berbayar pernah diterapkan di Kota Bogor. Namun sempat diberhentikan karena berdasarkan evaluasi aturan kantong plastik berbayar tidak menimbulkan dampak pengurangan sampah plastik yang signifikan. Saat itu juga belum ada payung hukum yang jelas sehingga aturan ini urung dilaksanakan.

kantong-plastik-di-bogor-kurangi-41-ton-sampah, diakses tanggal 18 Maret 2019. 


\section{Pembinaan dan Pengawasan Terhadap Pelaku Produsen dan Pelaku Usaha Dalam Kaitannya Dengan Program Pengurangan Kantong Plastik}

Pemerintah Kota Bogor terus melakukan pengawasan terhadap pembatasan kantong plastik. Hal itu terus dilakukan dalam rangka implementasi Peraturan Walikota Nomor 61 Tahun 2018 tentang Pengurangan Penggunaan Kantong Plastik. Selain itu, sosialisasi dan monitoring terhadap pemberlakukan Perwali Pengurangan Penggunaan Kantong Plastik itu terus dilakukan agar Kota Bogor suatu saat bersih dari sampah plastik. Sosialisasi dan pengawasan dilakukan guna memastikan ketaatan para pelaku usaha dan konsumen dalam mengurangi sampah plastik. Pembinaan dan monitoring ini gencar dilaksanakan guna memberikan pemahaman dan edukasi bagi masyarakat agar meengurangi penggunaan plastik. Hal itu lantaran sampah pkastik kini telah menjadi ancaman bagi keberlangsungan hidup manusia.

Peraturan Walikota Bogor Nomor 61 tahun 2018 mengatur masalah pembinaan dilakukan oleh Wali Kota atau pejabat yang melindungi lindungan hidup terhadap produsen dan pelaku usaha pembinaan dilakukan dengan cara sosialisasi, konsultasi dan juga pelatihan. Sama halnya dengan pembinaan, pengawasanpun dilakukan oleh Wali Kota atau pejabat yang membidangi lingkungan hidup dan juga perangkat daerah. Pengawasan dilakukan terhadap pelaku usaha, pusat perbelanjaan dan juga toko modern. Dalam hal melakkan pengawasan Wali Kota dapat membentuk tim yang terdiri dari unsur daerah terkait sebagai tugas pembantuan pengawasan. Apabila dari hasil pengawasan menunjukan adanya ketidaktaatan dari pelaku usaha, penyedia kantong plastik maupun pengguna kantong plastik maka Wali Kota dapat melakukan pembinaan.

Pembinaan dan pengawasan terhadap pelaku produsen dan pelaku usaha dalam kaitannya dengan program pengurangan kantong plastik tercantum dalam Pasal 16 dan Pasal 17 Perwali Nomor 61 Tahun 2018. Pasal 16 terkait tentang pembinaan sebagai berikut: (1) Wali Kota atau pejabat yang membidangi lingkungan hidup melakukan pembinaan terhadap produsen dan pelaku usaha. (2) Pembinaan sebagaimana dimaksud pada ayat (1) dilakukan terhadap usaha dan/atau kegiatan sebagai berikut: secara teknis menunjukkan adanya potensi untuk terjadinya pelanggaran persyaratan izin atau peraturan perundang-undangan, belum dilakukan upaya 
yang sungguh-sungguh untuk mencegah terjadinya pencemaran dan/atau kerusakan lingkungan, dan secara faktual adanya kesadaran untuk memenuhi persyaratan izin dan peraturan perundang-undangan namun memiliki keterbatasan. (3) Pembinaan sebagaimana dimaksud pada ayat (1) dapat dilakukan melalui sosialisasi, konsultasi, dan. pelatihan.

Adapun isi Pasal 17 mengenai pengawasan yang tertuang dalam Peraturan Walikota Nomor 61 Tahun 2018 sebagai berikut: (1) Wali Kota atau pejabat yang membidangi lingkungan hidup dan Perangkat Daerah yang terkait melakukan pengawasan terhadap Pelaku Usaha, Pusat Perbelanjaan, dan Toko Modern. (2) Dalam hal melakukan pengawasan sebagaimana dimaksud pada ayat (1) Wali Kota dapat membentuk tim yang terdiri dari unsur Perangkat Daerah terkait. (3) Dalam hal hasil pengawasan menunjukkan adanya ketidaktaatan dari pelaku usaha maupun pengguna kantong plastik maka Wali Kota melakukan pembinaan.

Berkaitan dengan pengawasan, ada Peraturan Daerah (Perda) yang terkait dengan Perwali Nomor 61 Tahun 2018, yaitu Perda Kota Bogor Nomor 9 Tahun 2012 tentang Pengelolaan Sampah, di mana Perda ini dibentuk karena Jumlah penduduk Kota Bogor yang besar dengan tingkat pertumbuhan yang tinggi mengakibatkan bertambahnya volume timbulan sampah. Di samping itu, pola konsumsi masyarakat memberikan kontribusi dalam menimbulkan jenis sampah yang semakin beragam, antara lain, sampah kemasan yang berbahaya dan/atau sulit diurai oleh proses alam.

Berdasarkan pemikiran sebagaimana diuraikan di atas, pembentukan Peraturan Daerah ini diperlukan dengan beberapa alasan. Pertama, kepastian hukum bagi rakyat untuk mendapatkan pelayanan pengelolaan sampah yang baik, aman, dan berwawasan lingkungan. Kedua, ketegasan mengenai larangan memasukkan dan/atau mengimpor sampah ke dalam wilayah daerah lainnya. Ketiga, ketertiban dalam penyelenggaraan pengelolaan sampah. Keempat, kejelasan tugas, wewenang, dan tanggung jawab pemerintah daerah dalam pengelolaan sampah. Adapun yang menjadi ranah pengawasan dari Perda tersebut adalah di mana Pemerintah daerah wajib melakukan pengawasan dan pengendalian terhadap pelaksanaan pengelolaan sampah. Pasal 64 dan 65 ayat (1) dan (2) Peraturan Daerah Kota Bogor Nomor 12 Tahun 2012 tentang Pengelolaan Sampah menyatakan bahwa pengawasan dan pengendalian sebagaimana 
Kewenangan Penyelenggaraan Program.....

\section{Nazaruddin Lathif}

dimaksud meliputi: Pemberian bimbingan, supervisi , dan konsultasi pengelolaan sampah, pendidikan dan pelatihan di bidang pengelolaan sampah, dan perencanaan, penelitian, pengembangan, pemantauan dan evaluasi pengelolaan sampah. Selain itu, pengawasan dan pengendalian yang dilakukan oleh pemerintah daerah Kota Bogor tersebut didasarkan pada norma, standar, prosedur, dan kriteria pengendalian dan pengawasan yang diatur dan sesuai dengan ketentuan peraturan perundang-undangan.

\section{Kendala-Kendala Yang Dihadapi Pemerintah Kota Bogor Dalam Program Pengurangan Kantong Plastik.}

Beberapa permasalahan atau kendalakendala yang dihadapi pemerintah Kota Bogor dalam program pengurangan kantong plastik, ada yang setuju dan tidak setuju dari para konsumen terutama ibu-ibu rumah tangga yang tidak ingin repot membawa kantong belanja atau membelinya di retail tersebut, dan dari para pelaku usaha atau retail masih bingung harus menyediakan kantong seperti apa dan adanya penolakan langsung dari konsumen terhadap retail tersebut. ${ }^{19}$

${ }^{19}$ Setiawati S.Hut, M.Si, Wawancara selaku Kasi Kemitraan dan Peningkatan Kapasitas Pada Dinas Lingkungan Hidup Kota Bogor pada hari senin
Sebenarmya berkaitan dengan pengurangan kantong plastik sudah pernah diterapkan oleh Kementerian Lingkungan Hidup dan Kehutanan dengan berupaya mengurangi sampah plastik dengan melakukan program uji coba kantong plastik berbayar. Pemerintah menerapkan kebijakan kantong plastik berbayar guna mengurangi pencemaran lingkungan dari sampah plastik. Program diuji coba mulai 21 Februari 2016 bersamaan dengan peringatan Hari Peduli Sampah Nasional. Dengan adanya kantong plastik berbayar, diharapkan masyarakat akan membawa kantong belanjanya.

Diuraikan dalam Surat Edaran Kementerian Lingkungan Hidup dan Kehutanan Direktorat Jenderal Pengelolaan Sampah, Limbah dan Bahan Berbahaya dan Beracun Nomor: S.1230/PSLB3-PS/2016 tentang Harga dan Mekanisme Penerapan Kantong Plastik Berbayar. Dalam surat edaran tersebut, minimal harga satu kantong plastik adalah Rp 200 (dua ratus rupiah). Ada pihak yang diuntungkan dengan Surat Edaran tersebut. Pengusaha retail dan toko modern bisa menurunkan biaya operasionalnya, karena kantong plastik yang sebelumnya digratiskan,

tanggal 22 April 2019 di Dinas Lingkungan Hidup Kota Bogor. 
sekarang menjadi tanggungjawab konsumen untuk membelinya. Dana hasil program plastik berbayar tidak dikelola oleh pemerintah, tetapi dikelola langsung oleh masing-masing pengusaha retail. Manajemen dana seperti ini merupakan praktik yang kurang baik ditinjau dari segi tata kelola kepemerintahan. Sebagian pengusaha menggunakan dana tersebut untuk membiaya program CSR (Corporate Social Responsibility). Penggunaan dana untuk kegiatan CSR menimbulkan pertanyaan: Mengapa program CSR harus didanai oleh konsumen.

Masyarakat (pembeli) adalah salah satu pihak yang dirugikan dalam kebijakan ini, karena harus membayar dua kali kantong plastik belanjaannya, karena sebenarnya penjual sudah memasukkan komponen biaya kantong plastik ke dalam harga barang yang dibeli. Selain itu harga minimal yang dikenakan untuk plastik berbayar juga sangat murah, yaitu minimal Rp 200 (dua ratus rupiah), sehingga cenderung tidak mengubah perilaku konsumen untuk membawa tas sendiri waktu berbelanja. Sementara itu payung hukum kebijakan plastik berbayar pun belum ditetapkan. Selama ini bentuknya baru berupa Surat Edaran, Kementerian Lingkungan Hidup dan Kehutanan belum menerbitkan Peratutan Menteri, sehingga
Pemerintah Daerah pun belum menerbitkan Peraturan Daerah untuk mengimplementasikannya.

Program Pengurangan Kantong Plastik dalam Peraturan Walikota Kota Bogor menjadi kendala karena masih belum dapat diterapkan di seluruh pusat perbelanjaan. Hanya pusat perbelanjaan modern atau retail modern saja yang baru dapat diterapkan dengan melakukan sosialisasi terlebih dahulu. Untuk pusat perbelanjaan tradisional atau pasar tradisional nantinya untuk kedepan akan dicoba untuk diterapkan.

Adapun yang menjadi permasalahan lain dalam hal mengurangi penggunaan plastik sekali pakai dan kantong plastik apabila tidak tersedia bahan pengganti yang memiliki kualitas sepadan dan lebih praktis. Apalagi sampai saat ini kantong plastik menjadi pembungkus yang murah dan tersedia secara masal. Memang terdapat tawaran untuk mengganti kantong plastik dengan menggunakan kantong kertas atau kantong kain. Permasalahannya kembali yaitu belum tersedia secara masal dan harganya belum mampu lebih murah dari kantong plastik. Begitu juga untuk pembungkus plastik sekali pakai pada bahan makanan, solusinya adalah mengganti dengan menggunakan bahan alami, yang mudah terurai. 
Kewenangan Penyelenggaraan Program.....

\section{Nazaruddin Lathif}

Khusus untuk kantong plastik memang terdapat himbauan kepada konsumen untuk membawa tas belanja, tetapi permasalahannnya kemudian bagaimana jika barang yang dibeli melebihi daya tampung tas belanja yang dibawa. Permasalahan yang ada harus segera diantisipasi dan disiapkan solusinya sehingga upaya pengurangan buangan plastik dapat dilakukan dengan tetap memperhatikan kenyamanan konsumen.

Berkaitan dengan penerapan Perwali Kota Bogor Nomor 61 Tahun 2018 tentang Pengurangan Penggunaan Kantong Plastik, konsumen dihadapkan sebuah dilema atau permasalahan di mana apabila konsumen pada saat berbelanja di toko retail atau toko modern, tidak diberikan kantong pembungkus belanja, namun konsumen diberikan pilihan untuk dapat memilih membawa belanjaan dengan cara tidak menggunakan kantong belanja atau membayar dengan menggunakan kantong pengganti plastik yang disediakan oleh retail toko modern maka kasir menginformasikan ada biaya yang harus dikeluarkan, atau membawa kantong belanja sendiri, atau bisa juga menggunakan kardus yang biasanya tersedia di beberapa supermarket besar sebagai wadah belanjanya. Petugas di kasir biasanya selalu menanyakan, apakah konsumen membawa kantong sendiri, atau mau menggunakan kantong yang disediakan retail toko modern.

Adanya kebijakan tersebut diharapkan dapat menimbulkan kesadaran dan kepedulian bagi masyarakat untuk mengurangi atau bahkan mendaur ulang sampah plastiknya. Adapun di satu sisi sebaliknya konsumen yang merasa keberatan membayar kantong plastik, berpendapat bahwa kebijakan tersebut hanya menguntungkan pihak pemilik retail modern saja dan makin membebani rakyat di mana pengusaha retail dan toko modern bisa menurunkan biaya operasionalnya, karena kantong plastik yang sebelumnya digratiskan, sekarang menjadi tanggungjawab konsumen untuk membelinya.

Dana hasil program plastik berbayar tidak dikelola oleh pemerintah, tetapi dikelola langsung oleh masing-masing pengusaha retail . Manajemen dana seperti ini merupakan praktik yang kurang baik ditinjau dari segi tata kelola kepemerintahan. Sebagian pengusaha menggunakan dana tersebut untuk membiaya program CSR (Corporate Social Responsibility). Selain itu, keengganan konsumen membayar kantong plastik karena ada anggapan bahwa kepedulian terhadap sampah kantong plastik seharusnya adalah kepedulian dan tanggung jawab bersama, jangan hanya menjadi beban konsumen 
semata. Oleh karena itu pemerintahlah yang dinilai oleh sebagian konsumen yang paling bertanggung jawab terkait pengelolaan sampah plastik tersebut.

Di dalam pembentukan suatu produk hukum khususnya Peraturan Walikota harus menerapkan asas keadilan. Sehingga dapat menghasilkan produk hukum yang adil pula khususnya bagi masyarakat. Berbicara mengenai pembentukan dan hasil produk hukum yang adil, tidak bisa lepas dari definisi atau pengertian tentang keadilan itu sendiri. Hukum tidak identik dengan keadilan, tetapi di dalam hukum ada kecenderungan untuk menginginkan keadilan, yaitu sikap tidak memihak (equality). Bukti bahwa hukum mengarah pada keadilan adalah bahwa undang-undang memberi ketentuan yang bersifat umum sehingga berlaku sama terhadap semua orang (equality before the law). Dapat disimpulkan bahwa hukum itu bersifat umum, mengikat semua orang, dan bersifat menyamaratakan. Namun, keadilan itu bersifat subyektif, individualistis, dan tidak bersifat menyamaratakan. Asas keadilan sangat penting untuk diterapkan dalam pembentukan suatu produk hukum. Penerapan asas keadilan dalam pembuatan produk hukum nantinya akan berdampak pada penerapan produk hukum itu sendiri.
Asas-asas yang harus dikandung dalam materi muatan Peraturan Perundang-undangan di Negara Republik Indonesia dirumuskan dalam Pasal 6 ayat (1) Undang-Undang Nomor 12 Tahun 2011 tentang Pembentukan Peraturan Perundang-undangan, adalah sebagai berikut: (1) Materi muatan Peraturan Perundang-undangan harus mencerminkan asas: a. pengayoman; b. kemanusiaan; c. kebangsaan; d. kekeluargaan; e kenusantaraan; f. bhinneka tunggal ika; g. keadilan; h. kesamaan kedudukan dalam hukum dan pemerintahan; i. ketertiban dan kepastian hukum; dan/atau j. keseimbangan, keserasian, dan keselarasan. Asas Keadilan tersebut bahwa setiap materi peraturan perundangundangan harus mencerminkan keadilan secara proporsional bagi setiap warga negara tanpa terkecuali. Sehingga dalam proses pembentukan undang-undang diharapakan agar dapat menerapkan asas keadilan.

Jika kita telaah peraturan di atas, sangatlah jelas jika dalam pembentukan peraturan perundang-undangan harus memenuhi asas keadilan. Terkait dengan Peraturan Walikota Bogor Nomor 61 Tahun 2018 tentang Pengurangan Penggunaan Kantong Plastik, berkaitan dengan nilai keadilan seharusnya peraturan tersebut harus melihat keadilan bagi konsumen, jangan 
Kewenangan Penyelenggaraan Program.....

\section{Nazaruddin Lathif}

sampai sebaliknya justru masyarakat atau konsumen yang menjadi korban karena adanya peraturan tersebut. Berkaitan dengan pengurangan kantong plastik semestinya bukan konsumen atau masyarakat yang menjadi korban dengan berbelanja tidak diberikan kantong plastik atau dengan cara membeli wadah pengganti kantong plastik yang harganya jauh di atas harga plastik.

Dikeluarkannya Perwali menimbulkan dampak positif dan juga negatif. Dampak positif dapat dilihat dengan semakin berkurangnya sampah plastik di lingkungan Kota Bogor, tetapi di satu sisi memberikan dampak negatif kepada konsumen atau masyarakat yang diberatkan karena adanya peraturan tersebut. Di mana masyarakat atau konsumen diharuskan menanggung beban atau biaya dalam hal pembelian kantong atau tas belanja.

Berkaitan dengan nilai keadilan, di lain pihak adanya kekurangan dalam penerapan Perwali Nomor 61 Tahun 2018 tentang Pengurangan Penggunaan Kantong Plastik ini, di mana dalam Perwali ini, berkaitan dengan penetapan kawasan pengurangan penggunaan kantong plastik sebagaimana tercantum dalam Pasal 8 Perwali Nomor 61 Tahun 2018 tentang Pengurangan Penggunaan Kantong Plastik belum dapat diterapkan di wilayah kawasan pusat perbelanjaan tradisional.

Kantong Plastik ini baru dapat diterapkan di retail modern atau toko modern saja di mana penggunaan plastik sekali pakai jika dicermati lebih banyak digunakan di pasar-pasar tradisional, seperti untuk membungkus minyak goreng, ikan segar, terasi hingga jajanan dan buah segar. Bahkan pada pasar tradisional saat ini penggunaan kantong plastik sekali pakai juga menjadi hal yang lumrah, apalagi kantong plastik tipis. Berbeda dengan kantong plastik yang disediakan toko modern yang cenderung bisa dipakai lebih dari sekali, apalagi kantong plastik yang dikeluarkan pasar modern juga sering dijadian bagian dari promosi dengan menempelkan nama toko. Begitu pula terkait dengan pembinaan dan juga pengawasan sebagaimana tercantum dalam Pasal 16 dan Pasal 17 Perwali Nomor 61 Tahun 2018 tentang Pengurangan Penggunaan Kantong Plastik baru dapat diterapkan di kawasan pusat perbelanjaan dan juga toko modern.

Menurut penulis, Peraturan Walikota Bogor Nomor 61 Tahun 2018 tentang Pengurangan Penggunaan Kantong Plastik ini kurang tepat jika konsepnya hanya untuk menekan atau mengurangi kantong plastik. Seharusnya peraturan tersebut mencari solusi atau jalan keluar bagaimana sampah kantong 
plastik berkurang tapi tanpa harus membebankan pihak konsumen atau masyarakat. Misalnya dengan jalan keluar atau memberikan solusi dengan cara menerapkan kantong plastik yang bersifat ekolabel atau ramah lingkungan dan sesuai dengan Standar Nasional Indonesia (SNI) yang tanpa harus melibatkan masyarakat atau konsumen untuk menanggung beban biaya pembayarannya.

Dengan memperhatikan permasalahan dan kendala yang ada di atas maka pemerintah tidak hanya cukup menyediakan aturan pengurangan bahan buangan plastik dan menyediakan bahan alternatif pengganti, tetapi juga perlu menyiapkan pengelolaan bahan buangan plastik. Penyiapan tata kelola bahan buangan plastik menjadi penting agar masyarakat juga dapat berperan dalam pengumpulan bahan buangan plastik. Selama ini beberapa masyarakat dan kelompok masyarakat telah secara sadar mengumpulkan bahan buangan kantong plastik dan plastik sekali pakai, tapi kemudian tidak menemukan alur kemana bahan tersebut harus dibawa untuk diolah menjadi bahan yang lebih berguna.

Penerapan program pengurangan kantong plastik, pada awalnya mengundang 24 (dua puluh empat) pelaku usaha dan toko modern, di mana yang dimaksud dengan pelaku usaha adalah setiap orang perseorangan atau badan usaha, baik berbentuk badan hukum maupun bukan badan hukum yang didirikan dan berkedudukan atau melakukan kegiatan dalam wilayah hukum negara Republik Indonesia, baik sendiri maupun bersama-sama melalui perjanjian menyelenggarakan kegiatan usaha dalam berbagai bidang ekonomi. Kemudian dilakukan diskusi bahwa nantinya Pemerintah Kota Bogor akan mengeluarkan Perwali yang berkaitan dengan pengurangan penggunaan sampah plastik, lalu kemudian di sosialisasikan melalui indoor maupun outdoor, indoor seperti pusat perbelanjaan yangg besar setiap hari sabtu dan minggu dengan target kepada konsumen dan kasir di retail tersebut, untuk sosialisasi outdoor di lakukan di taman taman dan sekolah, dan mulai di sosialisaikannya atau mulai di terapkannya tanggal 1 Desember 2018. Kemudian setelah itu, 3 (tiga) bulan kedepannya melakukan evaluasi ke pusat perbelanjaan yang sudah setuju menerapkan 
Kewenangan Penyelenggaraan Program.....

\section{Nazaruddin Lathif}

peraturan untuk di pantau penggunaannya. ${ }^{20}$

\section{PENUTUP}

Pemerintah Kota Bogor menyelenggarakan program pengurangan kantong plastik berdasarkan Peraturan Walikota Nomor 61 Tahun 2018 tentang Pengurangan Penggunaan Kantong Plastik. Namun Peraturan Walikota tersebut mendapati kendala dalam penyelenggaraan program pengurangan kantong plastik, yakni ada yang setuju dan tidak setuju dari para konsumen, terutama ibu-ibu rumah tangga yang tidak ingin repot membawa kantong belanja atau membelinya di retail tersebut, dan dari para pelaku usaha atau retail masih bingung harus menyediakan kantong seperti apa dan terlebih adanya penolakan langsung dari konsumen terhadap retail tersebut karena pengganti kantong plastik yang disediakan relatif mahal. Selain itu, Peraturan Walikota tersebut menimbulkan dampak positif dan negatif. Dampak positif semakin berkurangnya sampah plastik di lingkungan Kota Bogor, sedangkan dampak negatif konsumen atau masyarakat diharuskan

\footnotetext{
${ }^{20}$ Wawancara dengan Setiawati S.Hut, M.Si,
} selaku Kasi Kemitraan dan Peningkatan Kapasitas Pada Dinas Lingkungan Hidup Pemerintah Kota Bogor. menanggung beban atau biaya dalam hal pembelian kantong atau tas belanja.

Berkaitan dengan nilai keadilan, adanya kekurangan dalam penerapan Peraturan Walikora Nomor 61 Tahun 2018 tentang Pengurangan Penggunaan Kantong Plastik ini berkaitan dengan penetapan kawasan pengurangan penggunaan kantong plastik. Peraturan Walikota ini kurang tepat jika konsepnya hanya untuk menekan atau mengurangi kantong plastik. Seharusnya peraturan tersebut mencari solusi atau jalan keluar bagaimana sampah kantong plastik berkurang tapi tanpa harus membebankan pihak konsumen atau masyarakat. Misalnya dengan jalan keluar atau memberikan solusi dengan cara menerapkan kantong plastik yang bersifat ekolabel atau ramah lingkungan dan sesuai dengan Standar Nasional Indonesia (SNI) yang tanpa harus melibatkan masyarakat atau konsumen untuk menanggung beban biaya pembayarannya. Pemerintah tidak hanya menyediakan aturan pengurangan bahan buangan plastik dan menyediakan bahan alternatif pengganti, tetapi juga perlu menyiapkan pengelolaan bahan buangan plastik. 
Ada empat sarana dalam penelitian ini. Pertama, Pemerintah Kota Bogor tidak hanya menyasar kepada retail modern saja, akan tetapi juga menyasar kepada pasar tradisional karena salah satu penyumbang sampah kantong plastik terbesar ialah pasar tradisional. Kedua, perlu adanya pengaturan yang mewajibkan pemerintah pusat untuk menekan produsen biji plastik untuk menambahkan zat aditif dalam memproduksi kantong plastik, sehingga menghasilkan kantong plastik ramah lingkungan yang relatif mudah terdegradasi. Ketiga, pengusaha retail perlu menyediakan kantong belanja ramah lingkungan (kantong dari tapioka/kardus/kertas/serat dan sebagainya). Keempat, Pemerintah Kota Bogor perlu melakukan sosialisasi kepada masyarakat agar belanja membawa kantong belanja yang ramah lingkungan yang dapat digunakan berulang-ulang atau tidak sekali pakai dengan tujuan untuk mengurangi sampai plastik dan menjaga kelestarian lingkungan khususnya lingkungan daerah Kota Bogor.

\section{DAFTAR PUSTAKA}

Akib, Muhammad, Hukum Lingkungan, Perspektif Global Dan Nasional, Edisi Revisi (Jakarta: Raja Grafindo Persada, 2014)

Astuti, Arieyanti Dwi, 'Penerapan Kantong Plastik Berbayar Sebagai Upaya Mereduksi Penggunaan Kantong
Plastik', Jurnal Litbang, 12.1 (2016), 37

Hamzah, Andi, Penegakan Hukum Lingkungan (Jakarta: Sinar Grafika, 2005)

Kartika, Ayi Indah Novianti; Lindawati, 'Pengaruh Green Marketing Kebijakan Kantong Plastik Berbayar Terhadap Green Behaviour Masyarakat Kota Bogor', Jurnal Riset Manajemen Dan Bisnis, 2.1, 82

Marzuki, Peter Mahmud, Penelitian Hukum (Jakarta: Kencana Prenada Media Group, 2010)

Nugraha, Safri, Hukum Administrasi Negara (Jakarta: FH UI, 2007)

Qodriyatun, Sri Nurhayati, 'Sampah Plastik: Dampaknya Terhadap Pariwisata Dan Solusinya', Jurnal Kajian Singkat Terhadap Isu Aktual Dan Strategis, 10.23 (2018), 13

Ririn Setyowati, Surahma Asti Mulasari, 'Pengetahuan Dan Perilaku Ibu Rumah Tangga Dalam Pengelolaan Sampah Plastik', Jurnal Kesehatan Masyarakat Nasional, 7.12 (2011), 256

Shochib, Rosita, 'Pengelolaan Sampah Kantor Secara Terpadu (Studi Kasus Kantor BPPT), Jurnal Rekayasa Lingkungan', Jurnal Rekayasa Lingkungan, 7.2 (2011), 154

Soekanto, Soerjono, Pengantar Penelitian Hukum (Jakarta: UI Press, 1986)

Syamsuri, Jailan Sahili; Mimien Henie Irawati Al Muhdar; Fachtur Rohman; Istamar, 'Sistem Pengelolaan Dan Upaya Penanggulangan Sampah Di Kelurahan Dufa-Dufa Kota Ternate', Jurnal Bioedukasi, 4.2 (2016), 478

Usman, Said, 'Strategi Pengelolaan Sampah Rumah Tangga Di Kota Tarakan 
Kewenangan Penyelenggaraan Program.....

Nazaruddin Lathif

Kalimantan Utara, Jurnal Ekonomi Pembangunan', Jurnal Ekonomi Pembangunan, 5.3 (2016), 350

Vioya, Arrauda, 'Tahapan Perkembangan Kawasan Metropolitan Jakarta', Jurnal Perencanaan Wilayah Dan Kota, 21.3 (2010), 215

Wibawa, I Putu Sastra, 'Politik Hukum Perlindungan Dan Pengelolaan Menuju Ekokrasi Indonesia', Kanun Jurnal Ilmu Hukum, 18.1 (2016), 1
Wisoyodharmo, Firman L Sahwan; Joko Heru Martono; Sri Wahyono; Lies A, 'Sistem Pengelolaan Libah Plastik Di Indonesia, Jurnal Teknologi Lingkungan', Jurnal Teknologi Lingkungan, 6.1 (2011), 311

Yuriandala, Hijrah Purnama Putra; Yebi, 'Studi Pemanfaatan Sampah Plastik Menjadi Produk Dan Jasa Kreatif, Urnal Sains Dan Teknologi Lingkungan', Jurnal Sains Dan Teknologi Lingkungan, 2.1 (2010), 21 


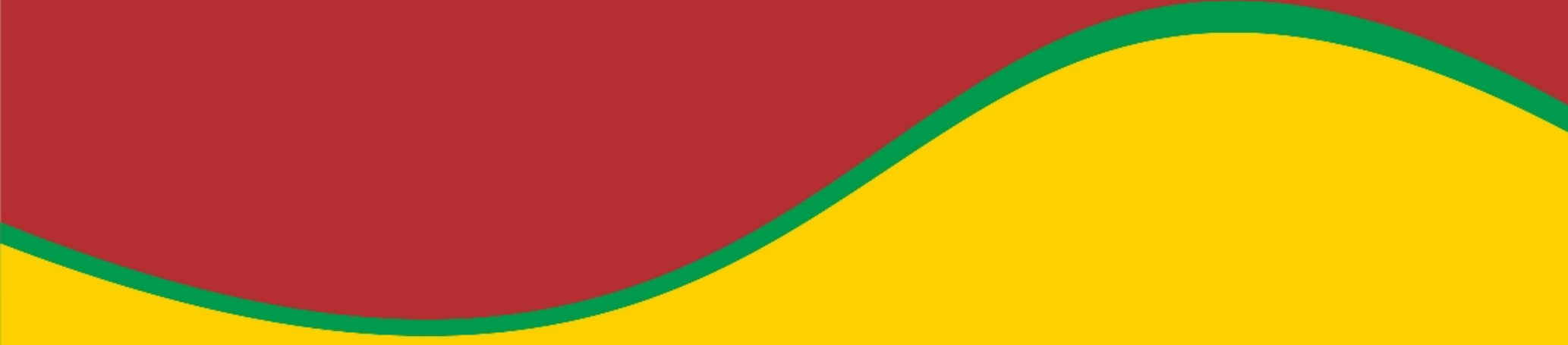

Magister Ilmu Hukum

Universitas Lancang Kuning

Jl. Yos Sudarso Km. 8 Umban Sari, Rumbai, Pekanbaru-Riau http://journal.unilak.ac.id/index.php/gh/index

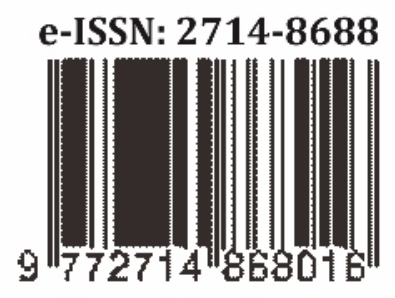

